\title{
Kepastian Hukum Pelaksanaan Khiyar Syarat Dalam Bai' Salam Online Melalui Instagram
}

\author{
Wahyu; Rahmadi Indra Tektona \\ Sekolah Tinggi Ilmu Hukum Sultan Adam Banjarmasin; Universitas Negeri \\ Jember \\ vechter.27@gmail.com; rahmadiindra@unej.ac.id
}

\begin{abstract}
Islam strongly emphasizes that all economic activities carried out by humans in the world are an accountability that must be in accordance with Islamic law. In the Sharia economy there are khiyar rights which are expected to provide good benefits in the sale and purchase agreement and make buying and selling activities in accordance with the principles of Islamic law, it is consensual and also providing benefits to the parties in accordance with the provisions in Islamic law and the existence of willingness or sincerity in buying and selling activities in accordance with the Koran and hadith. Currently, many buying and selling transactions are carried out online, one of which is using the social media, Instagram, which has millions of users who can exceed time and space. Many business actors ranging from housewives, students, state employees, private employees who post goods to be traded on Instagram, behind this convenience, of course there are problems, it is the existing image and the merchant's reputation is something that is highly valued in online trading. The problem that arises in the online buying and selling contract is the mismatch of goods with pictures and descriptions on social media resulting in a one-sided cancellation of the purchase of ordered goods by the buyer and this results in losses to the seller, even though before the transaction the two parties have mutually agreed. The research objective of this paper was to analyze legal certainty in the implementation of khiyar in purchasing ordered goods in online buying and selling transactions via Instagram, the research method used is normative juridical, the results of research on the form of legal certainty in the implementation of khiyar.
\end{abstract}

Keywords: Legal certainty, Khiyar Syarat, Bai’ Salam Online

\section{Pendahuluan}

Saat ini transaksi dalam E-commerce hampir seluruhnya dikerjakan menggunakan teknologi berbasis web. Istilah Ecommerce mengacu pada sebuah transaksi yang dilakukan melalui sebuah media elektronika seperti internet, yang meliputi web, internet, dan extranet. ${ }^{1}$ Cara transaksi juga menggunakan berbagai sarana yang ada dalam dunia maya. Transaksi di dunia maya umumnya

\footnotetext{
${ }^{1}$ Imam Mustofa, “Transaksi Elektronik (E-commerce) dalam Perspektif Fiqih", Jurnal Hukum
} Islam, Vol. 10, No. 2 (Desember 2012), 159-160. 
menggunakan media sosial, seperti Instagram, Twitter, Facebook dan media sosial lainnya. Dalam transaksi di dunia maya, antara para pihak yang bertransaksi tidak bertemu langsung, baik secara audio maupun audio visual. Selain itu, komunikasi antara keduanya dapat melalui tulisan, seperti DM (Direct Message) melalui Instagram, chat melalui Whatsapp, line dan sosial media lainnya. Jual beli melalui media elektronik adalah transaksi jual beli yang dilakukan melalui teknologi modern sebagaimana disebutkan keabsahannya tergantung pada terpenuhi atau tidaknya rukun dan syarat yang berlaku dalam jual beli. Apabila rukun dan syarat terpenuhi maka transaksi semacam ini sah. Sah sebagai sebuah transaksi yang mengikat, dan sebaliknya, apabila tidak terpenuhi maka tidak sah. ${ }^{2}$ Seorang pengusaha online sangat bisa menggunakan instagram sebagai media pemasaran produk yang dijual. Alasannya, instagram adalah salah satu aplikasi yang menjanjikan untuk dijadikan senjata dalam content strategy. Selain itu, foto atau gambar termasuk dalam kategori konten yang paling appealing buat pelanggan, baik itu yang menjual produk, maupun yang menawarkan jasa.

Muamalah sebagai bidang yang mengatur hubungan seseorang dengan orang lain, seperti kegiatan jual beli atau tukar menukar harta. Maka dari itu muncullah fiqh muamalah sebagai hukum yang bersifat praktis yang diperoleh dari dalil-dalil yang terperinci untuk mengatur hubungan keperdataan seseorang dengan orang lain dalam hal persoalan ekonomi. ${ }^{3}$ Bidang muamalah merupakan bidang yang sangat luas ruang lingkupnya, sehingga dalam memecahkan persoalan muamalah diperlukan ijtihad, dalam ijtihad tentunya harus berdasarkan prinsip hukum Islam yang dijadikan pedoman dalam melakukan aktivitas muamalah, salah satunya aktivitas jual beli. Prinsip-prinsip hukum Islam yang harus dijadikan pedoman dalam melakukan aktivitas muamalah yaitu pada dasarnya segala bentuk muamalah adalah mubah (boleh) kecuali yang telah ditentukan lain oleh Al-Qur'an dan Sunnah Rasul. ${ }^{4}$ Dalam Al-Qur'an dan Hadist kegiatan jual beli merupakan suatu pilihan pekerjaan yang diakui dan termasuk pekerjaan yang mulia. Akan

${ }^{2}$ Ibid, 170-171.

${ }^{3}$ Zainuddin Ali, Hukum Ekonomi Syariah (Jakarta: Sinar Grafika, 2008), 118-119.

${ }^{4}$ Heri Sudarsono, Konsep Ekonomi Islam Suatu Pengantar (Yogyakarta: Ekonisia, 2003), 30. 
tetapi terdapat suatu hal yang sangat perlu diperhatikan pada kegiatan jual beli yaitu dalam hal kejujuran, kejujuran itulah yang akan membuat kegiatan jual beli menjadi mulia di mata Allah SWT.

Jual beli dalam Islam termasuk dalam salah satu kegiatan muamalah. Kegiatan muamalah adalah kegiatan atau transaksi yang dilakukan oleh manusia dengan manusia dalam kehidupannya yang sesuai dengan syariat Islam. ${ }^{5}$ Dalam Buku III Kitab Undang-Undang Hukum Perdata Pasal 1457 disebutkan bahwa Jual beli adalah suatu persetujuan dengan mana pihak yang satu mengikatkan dirinya untuk menyerahkan suatu barang, dan pihak yang lain untuk membayar harga yang diperjanjikan, sedangkan di dalam Islam jual beli (al-bai') merupakan salah satu dari kegiatan muamalah yang diperbolehkan dan sangat dianjurkan dalam syariat Islam, dalam Islam muamalah tidak hanya mencakup jual beli, namun juga mencakup transaksi utang piutang, sewa menyewa dan banyak transaksi lainnya yang tidak melanggar syariat Islam. Pada akad jual beli, pembeli sebagai seseorang yang akan melakukan pembelian pada suatu barang memiliki hak untuk melangsungkan atau membatalkan suatu akad jual beli yang telah disepakati. Hak memilih ini di dalam Islam dikenal dengan istilah khiyar yang diharapkan dapat memberikan rasa kerelaan yang lebih antara kedua belah pihak yang sedang melakukan jual beli agar objek yang diperjual belikan sesuai dengan apa yang diinginkan supaya ketentuan di dalam syariat Islam tentang kerelaan atau keikhlasan pada kegiatan jual beli dapat diterapkan dengan baik sesuai dengan yang ditetapkan di dalam Al-Qur'an dan Hadist.

Pada kitab fikih Islam jual beli pesanan disebut jual beli salam (bai al-salam) atau jual beli salaf (bai al-salaf) adalah jual beli barang dengan cara pemesanan yang pembayaran harganya terlebih dahulu dengan syarat dan ketentuan khusus. ${ }^{6}$ Dalam Islam jual beli menurut ulama Malikiyah, Syafi'iyah dan Hambaliyah adalah

${ }^{5} \mathrm{M}$ Yazid, Fiqh Muamalah dan Implementasinya dalam Lembaga Keuangan Syari'ah, Cetakan Pertama (Yogyakarta: Logung Pustaka, 2009), 3.

${ }^{6}$ Jaih Mubarok, Hasanudin, Fikih Mu'amalah Maliyyah Akad Jual Beli (Bandung: Simbioasa Rekatama Media, 2018), 261. 
"saling tukar menukar harta dengan harta dalam bentuk pemindahan milik dan pemilikan". ${ }^{7}$ Sedangkan menurut ulama Hanafiyah mendefinisikan jual beli adalah "saling menukar harta dengan harta melalui cara tertentu". ${ }^{8}$ Saat ini, jual beli tidak terbatas pada transaksi di pasar tradisional. ${ }^{9}$ Jual beli online ini sama dengan akad pesan memesan yang dalam Islam disebut akad salam yang awalnya akad tersebut dilarang karena merupakan jual beli barang yang tidak ada wujudnya (ba'iul ma'dum). Namun, banyaknya kebutuhan manusia akan akad salam ini diperbolehkan karena adanya hajat. ${ }^{10}$

Khiyar disyariatkan bertujuan untuk memelihara keadaan saling rela dan menjaga maslahat kedua pihak yang berakad, atau mencegah bahaya kerugian yang bisa jadi menimpa salah satu pihak yang berakad. Khiyar Syarat, yaitu penjualan yang di dalamnya disyaratkan sesuatu baik oleh penjual maupun olah pembeli, seperti seseorang berkata, "saya jual rumah ini dengan harga Rp. 200.000.000 dengan syarat khiyar selama 3 (tiga) hari". Rasulullah SAW bersabda " kamu boleh khiyar pada setiap benda yang telah dibeli selama 3 (tiga) hari 3 (tiga) malam “(Riwayat Baihaqi). Pada akad jual beli, pembeli sebagai seseorang yang akan melakukan pembelian pada suatu barang memiliki hak untuk melangsungkan atau membatalkan suatu akad jual beli yang telah disepakati. Hak memilih ini di dalam islam dikenal dengan istilah khiyar. Dengan diterapkannya hak khiyar ini memberikan manfaat yang baik di dalam akad jual beli, khiyar akan membuat kegiatan jual beli berjalan sesuai dengan prinsip hukum Islam yaitu suka sama suka dan juga memberikan kemaslahatan bagi para pihak yang melakukan akad jual beli itu sendiri. Hak khiyar sendiri disyariatkan untuk menjamin kebebasan dan keadilan

\footnotetext{
${ }^{7}$ M. Noor Harisudin, Fiqh Muamalah 1 (Jember: Pena Salsabila, 2014), 23.

${ }^{8}$ M. Noor Harisudin, Fiqh Muamalah 1 (Jember: Pena Salsabila, 2014), 23.

${ }^{9}$ Moh. Agus Sifa'. "Mekanisme Pasar dalam Perspektif Islam”. Journal of Sharia Economics. 2(1). 2020, 30 .

${ }^{10}$ M. Noor Harisudin, Fiqh Muamalah 1 (Jember: Pena Salsabila, 2014), 9.
} 
bagi masing-masing pihak yang sedang melaksanakan transaksi. ${ }^{11}$ Sehingga hak khiyar merupakan ruang atau jangka waktu yang ditawarkan oleh fiqh muamalah untuk berfikir ulang, merenung dan saling mengkoreksi antar pihak terkait dengan obyek dan transaksi yang telah mereka lakukan. ${ }^{12}$ Khiyar sendiri memperbolehkan untuk meneruskan atau menunggu penyelesaian dan membatalkan akad jual beli tersebut.

\section{Metode Penelitian}

Metodologi merupakan cara kerja bagaimana menemukan atau memperoleh hasil yang konkrit dan juga metode tersebut merupakan cara utama mencapai tujuan. ${ }^{13}$ Tipe penelitian yang digunakan dalam artikel ini adalah yuridis normatif (Legal Research) yakni menemukan kebenaran koherensi, di mana penelitian ini menganalisis aturan hukum dengan norma hukum dan adakah norma yang berupa perintah atau larangan itu sesuai dengan prinsip hukum, serta apakah tindakan (act) seseorang sesuai dengan norma hukum (bukan hanya sesuai aturan hukum) atau prinsip hukum. ${ }^{14}$ Tipe penelitian yuridis normatif dilakukan dengan mengkaji berbagai macam aturan hukum yang bersifat formal seperti undang-undang, literatur-literatur, yang bersifat konsep teoritis yang kemudian dihubungkan dengan kepastian hukum dalam pelaksanaan khiyar dalam pembelian barang pesanan pada transaksi jual beli online melalui Instagram yang menjadi pokok pembahasan. ${ }^{15}$

\footnotetext{
${ }^{11}$ M Yazid, Fiqh Muamalah dan Implementasinya dalam Lembaga Keuangan Syari'ah, Cetakan Pertama (Yogyakarta: Logung Pustaka, 2009), 75.

${ }^{12}$ M Yazid, Fiqh Muamalah dan Implementasinya dalam Lembaga Keuangan Syari'ah, Cetakan Pertama (Yogyakarta: Logung Pustaka, 2009), 75.

${ }^{13}$ Peter Mahmud Marzuki, Penelitian Hukum, (Jakarta: Kencana Prenada Media Group, 2010), 27.

${ }^{14}$ Peter Mahmud Marzuki. Penelitian Hukum, Cetakan ke-9 (Jakarta: Kencana Prenada Media Group, 2014), 47.

15 Peter Mahmud Marzuki. Penelitian Hukum, Cetakan ke-9 (Jakarta: Kencana Prenada Media Group, 2014), 194.
} 
Ada beberapa pendekatan yang dapat digunakan dalam melakukan penelitian hukum. Dalam kaitannya dengan penelitian normatif dapat digunakan beberapa pendekatan berikut yaitu pendekatan perundang-undangan (statute approach), pendekatan konseptual (conceptual approach), pendekatan analisis (analiytical approach), dan pendekatan kasus (case approach). Ketiga pendekatan tersebut digunakan untuk menganalisis kepastian hukum dalam pelaksanaan khiyar dalam pembelian barang pesanan pada transaksi jual beli online melalui Instagram

Analisa bahan hukum merupakan suatu metode atau cara untuk menemukan jawaban atas kepastian hukum dalam pelaksanaan khiyar dalam pembelian barang pesanan pada transaksi jual beli online melalui Instagram melalui proses untuk menemukan jawaban atas permasalahan yang penulis ambil dengan melakukan langkah-langkah sebagai berikut: ${ }^{16}$

1. Mengidentifikasi fakta hukum dan mengeliminir hal-hal yang tidak relevan untuk menetapkan isu hukum yang hendak dipecahkan;

2. Mengumpulkan bahan-bahan hukum yang sekiranya dipandang mempunyai relevansi juga bahan-bahan non hukum;

3. Melakukan telaah atas isu hukum yang diajukan berdasarkan bahan- bahan yang telah dikumpulkan;

4. Menarik kesimpulan dalam bentuk argumentasi yang menjawab isu hukum; dan

5. Memberikan preskripsi berdasarkan argumentasi yang telah dibangun di dalam kesimpulan.

Hasil analisis tersebut kemudian dibahas untuk mendapatkan pemahaman yang jelas tentang kepastian hukum dalam pelaksanaan khiyar dalam pembelian barang pesanan pada transaksi jual beli online melalui Instagram sehingga dapat ditarik kesimpulan yang dapat dipertanggungjawabkan dengan meggunakan metode deduktif, yaitu cara pengambilan kesimpulan yang bersifat khusus, sehingga jawaban atas rumusan masalah dapat tercapai.

${ }^{16}$ Peter Mahmud Marzuki, Penelitian Hukum, Edisi Revisi (Jakarta: Kencana Prenada Media Group, 2016), 171. 


\section{Hasil dan Diskusi}

Jual beli berasal dari bahasa arab $A l-b a$ ' $i$ yang berarti menjual, mengganti dan menukar sesuatu dengan sesuatu lain. Dalam prakteknya, bahasa ini kadang digunakan untuk mengganti lawannya, yakni as-syira' (beli). Maka kata Al-ba'i berarti jual, tetapi juga bisa diartikan beli. Ada berbagai macam jenis jual beli dengan menyebutkan sifat dan jenisnya dan juga dengan cara pemesanan yaitu disebut jual beli salam dan jual beli istishna.

Menurut hukum islam akad As-Salam didefinisikan sebagai jual beli barang yang disebutkan sifatnya dalam tanggungan dengan imbalan (pembayaran) yang dilakukan saat itu juga. Adapun Salam secara termonologi adalah transaksi terhadap sesuatu yang dijelaskan sifatnya dalam tanggungan dalam suatu tempo dengan harga yang diberikan kontan di tempat transaksi. ${ }^{17}$ Ada beberapa pendapat para ulama tentang akad As-Salam ini yaitu: 1) Ulama fiqh mendefinisikan salam adalah menjual sesuatu (barang) yang penyerahannya ditangguhkan atau ditunda, ataupun bisa disebut menjual sesuatu yang jelas ciri-cirinya dengan pembayaran imbalan (modal) di awal sedangkan penyerahan barangnya diserahkan dikemudian hari. 2) Ulama Shafi'iyah dan Hanabilah mendefinisikan salam adalah perjanjian yang telah disepakati untuk membuat sebuah barang dengan ketentuan dan ciri-ciri yang diinginkan oleh pembeli, dengan membayar biayanya di awal dan penyerahan barangnya diserahkan dikemudian hari. ${ }^{18}$ 3) Para fuqaha mendefinisikannya sebagai transaksi atau suatu barang dengan kriteria tertentu yang berada dalam jaminan penjual dan diberikan dikemudian hari namun dengan harga tunai yang diterima ditempat transaksi. ${ }^{19}$

Jenis jual beli ini diperbolehkan oleh syariat Islam, walaupun barang yang dijual masih belum terwujud pada saat akad. Dalil yang menunjukkan bahwa jual

\footnotetext{
17 Miftahul Khairi, Ensiklopedia Fiqh Muamalah Dalam Pandangan 4 Madzhab, Cetakan-1 (Yogyakarta: Maktabah Al Khanif, 2009), 137.

${ }^{18}$ Abu Azam Al Hadi, Fikih Muamalah Kontemporer, Edisi Pertama, Cetakan Pertama (Depok: Rajawali Pers, 2017), 216.

${ }^{19}$ Shahih al-Fauzan, al-Mulakhkhas al-Fiqhi Juz 2 (Jakarta: Pustaka Ibnu Katsir, 2013), 91.
} 
beli ini sesuai dengan syariat Islam adalah nash. Imam ash-Shadiq a.s berkata, "Tidak apa-apa jual beli as-Salam jika engkau terangkan sifat-sifat barang yang engkau jual, panjang dan lebarnya, dan pada hewan jika engkau jelaskan (sifat) gigigigiya.

\section{Dasar Hukum Akad As-Salam}

Al-Qur'an

Qs. Al-Baqarah (2) 282 yang artinya: Hai orang-orang yang beriman, apabila kamu bermu'amalah tidak secara tunai untuk waktu yang ditentukan, hendaklah kamu menuliskannya. Dan hendaklah seorang penulis di antara kamu menuliskannya dengan benar. Dan janganlah penulis enggan menuliskannya sebagaimana Allah mengajarkannya, maka hendaklah ia menulis, dan hendaklah orang yang berhutang itu mengimlakkan (apa yang akan ditulis itu), dan hendaklah ia bertakwa kepada Allah Tuhannya, dan janganlah ia mengurangi sedikitpun daripada hutangnya. Jika yang berhutang itu orang yang lemah akalnya atau lemah (keadaannya) atau dia sendiri tidak mampu mengimlakkan, maka hendaklah walinya mengimlakkan dengan jujur. Dan persaksikanlah dengan dua orang saksi dari orang-orang lelaki (di antaramu). Jika tak ada dua orang lelaki, maka (boleh) seorang lelaki dan dua orang perempuan dari saksi-saksi yang kamu ridhai, supaya jika seorang lupa maka yang seorang mengingatkannya. Janganlah saksi-saksi itu enggan (memberi keterangan) apabila mereka dipanggil; dan janganlah kamu jemu menulis hutang itu, baik kecil maupun besar sampai batas waktu membayarnya. Yang demikian itu, lebih adil di sisi Allah dan lebih menguatkan persaksian dan lebih dekat kepada tidak (menimbulkan) keraguanmu. (Tulislah muamalah-mu itu), kecuali jika mu'amalah itu perdagangan tunai yang kamu jalankan di antara kamu, maka tidak ada dosa bagi kamu, (jika) kamu tidak menulisnya. Dan persaksikanlah apabila kamu berjual beli; dan janganlah penulis dan saksi saling sulit menyulitkan. Jika kamu lakukan (yang demikian), maka sesungguhnya hal itu adalah suatu kefasikan pada dirimu. Dan bertakwalah kepada Allah, Allah mengajarmu dan Allah Maha Mengetahui segala sesuatu.

\section{Hadist}


Hadist Nabi Muhammad SAW, yang artinya: "Sesungguhnya Rasulullah SAW. mendatangi Madinah mereka (penduduk) Madinah melakukan jual beli salaf selama 1 (satu) tahun, 2 (dua) tahun, dan 3 (tiga) tahun". Rasulullah SAW bersabda: “siapa saja yang melakukan jual beli salaf, lakukanlah jual beli salaf atas barang yang dapat diketahui dengan cara ditakar atau ditimbang, dan jangka waktu yang telah diketahui".

Ijma'

Ibn Al-Mundzir menjelaskan bahwa ulama sepakat (Ijma') bahwa jual beli salam termasuk di dalam jual beli yang diperbolehkan dikarenakan adanya kebutuhan untuk melakukan kebutuhan tersebut. ${ }^{20}$

\section{Perbedaan As-Salam dengan Jual Beli Biasa.}

Akad As Salam dengan jual beli biasa memiliki beberapa perbedaan, yaitu:

Tabel 1. Perbedaan Jual Beli Salam dan Jual Beli Biasa

\begin{tabular}{|l|l|l|}
\hline No & \multicolumn{1}{|c|}{ Jual beli salam } & \multicolumn{1}{|c|}{ Jual beli biasa } \\
\hline 1 & $\begin{array}{l}\text { Menurut Hanafiyah, Ra's al-mal } \\
\text { tidak boleh diganti sebelum serah } \\
\text { terima dengan penjual (muslam } \\
\text { ilyh), serah terima ra'sul mal } \\
\text { merupakan syarat bagi sah-nya } \\
\text { akad Salam. }\end{array}$ & $\begin{array}{l}\text { Di dalam jual beli biasa, harga bisa } \\
\text { diganti jika berupa hutang, dan tidak } \\
\text { harus diserahterimakan saat akad. } \\
\text { Untuk muslam fyh tidak boleh ada } \\
\text { penggantinya, begitu juga dengan } \\
\text { objek akad jual beli yang telah } \\
\text { disepakati. }\end{array}$ \\
\hline 2 & $\begin{array}{l}\text { Dalam akad Salam muslam } \\
\text { boleh melakukan ibra' atas } \\
\text { muslam fyh, tidak dalam jual beli, } \\
\text { objek akad harus diserahkan. }\end{array}$ & $\begin{array}{l}\text { Penjual (muslam ilyh) tidak } \\
\text { diperbolehkan meminta muslam } \\
\text { untuk lepas dari ra'sul mal tanpa } \\
\text { persetujuannya, jika muslam } \\
\text { sepakat, maka akad Salam batal. } \\
\text { Serah terima ra'sul maal merupakan } \\
\text { syarat syahnya akad Salam, berbeda }\end{array}$ \\
\hline
\end{tabular}

${ }^{20}$ Shahih al-Fauzan, al-Mulakhkhas al-Fiqhi Juz 2 (Jakarta: Pustaka Ibnu Katsir, 2013), 256. 


\begin{tabular}{|l|l|l|}
\hline & & $\begin{array}{l}\text { dengan serah terima harga dalam } \\
\text { jual beli. }\end{array}$ \\
\hline 3 & $\begin{array}{l}\text { Pembayaran dilakukan di awal } \\
\text { pada saat pemesanan. }\end{array}$ & $\begin{array}{l}\text { Pembayaran dilakukan bersamaan } \\
\text { dengan penyerahan barang. }\end{array}$ \\
\hline
\end{tabular}

Sumber : Buku berjudul Pengantar Fiqh Muamalah karya Dimyauddin Djuwaini. Tahun 2015.

\section{Berakhirnya Akad As-Salam}

Jual beli salam merupakan jual beli berjangka waktu karena terdapat utang yang harus ditunaikan oleh penjual. Akad jual beli salam berakhir dengan beberapa cara yaitu: ${ }^{21}$

1. Pihak penjual (muslam ilaih) menyerahkan objek yang dipesan kepada pembeli atau wakilnya dan diterima oleh pihak pembeli.

2. Apabila objek yang diterima tidak sesuai dengan deskripsi pada saat berlangsungnya akad, maka pihak pembeli berhak memperoleh hak yaitu:

a. Meminta penggantian barang kepada penjual dan barang yang tidak sesuai dikembalikan kepada penjual.

b. Melakukan iqalah (pembatalan) akad salam jika penjual tidak dapat menyerahkan barang yang sesuai dengan deskripsi pada majelis akad. Dalam hal ini penjual wajib mengembalikan harga kepada pembeli.

3. Melakukan ibra', yaitu pihak pembeli membebaskan pihak penjual dari kewajiban untuk mewujudkan barang yang telah dipesan.

4. Melakukan akad hiwalah, yaitu pihak pembeli mengalihkan piutangnya kepada pihak lain.

Secara terminologi, Khiyar adalah hak pilih bagi salah satu atau kedua pihak yang melaksanakan transaksi untuk memilih antara dua hal yang disukainya, melangsungkan transaksi atau membatalkannya, sesuai dengan kondisi masingmasing pihak yang melakukan transaksi. Pasal 20 butir 8 Kompilasi Hukum Ekonomi Syariah (KHES): Khiyar adalah hak pilih bagi penjual dan pembeli untuk melanjutkan atau membatalkan akad jual-beli yang dilakukannya. Secara lughawi,

${ }^{21}$ Shahih al-Fauzan, al-Mulakhkhas al-Fiqhi Juz 2 (Jakarta: Pustaka Ibnu Katsir,2013), 261-262. 
Khiyar adalah pilihan, sedangkan secara istilahi pengertian khiyar adalah hak pilih bagi salah satu atau kedua belah pihak yang melaksanakan transaksi jual beli untuk melangsungkan atau membatalkan transaksi yang disepakati, disebabkan hal-hal tertentu yang membuat masing-masing atau salah satu pihak melakukan pilihan tersebut. Pilihan ini dapat dilakukan dalam berbagai macam sebab dan keadaan yang berbeda-beda. ${ }^{22}$ Khiyar Syarat adalah hak pilih yang ditetapkan bagi salah satu pihak yang berakad atau keduanya untuk meneruskan atau membatalkan jual beli, selama tenggat waktu yang ditentukan. ${ }^{23}$ Para ulama fiqh menyatakan bahwa khiyar syarat ini diperbolehkan karena bertujuan agar terpenuhinya hak-hak pembeli dari unsur penipuan yang mungkin bisa terjadi dari pihak penjual. Khiyar Syarat hanya berlaku dalam transaksi yang sifatnya mengikat kedua pihak, seperti transaksi jual beli, kerjasama dagang dan jaminan hutang. ${ }^{24}$

Menurut jumhur ulama figh masalah tenggang waktu dalam khiyar syarat harus jelas. Apabila tenggang waktu itu tidak jelas maka khiyar syarat tersebut tidak sah. Menurut ulama Malikiyah, jangka waktu dalam khiyar syarat mutlak diperbolehkan, tanpa ditentukan waktunya. Dalam hal semacam ini, menurut ulama malikiyah, hakim berhak menentukan jangka waktu yang pasti atau diserahkan kepada adat kebiasaan di masing-masing tempat. ${ }^{25}$

Menurut ulama fiqh syarat sahnya khiyar syarat ada dua yaitu: ${ }^{26}$

1. Dilakukan dalam jangka waktu khiyar.

2. Pembatalan itu diketahui pihak lain.

Menurut ulama fiqh syarat sah berakhirnya khiyar syarat ada lima yaitu: ${ }^{27}$

${ }^{22}$ Shahih al-Fauzan, al-Mulakhkhas al-Fiqhi Juz 2 (Jakarta: Pustaka Ibnu Katsir,2013), 261-262.

${ }^{23}$ M Yazid, Op. Cit, 77.

${ }^{24}$ Moh. Ah. Subhan, Hak Pilih (Khiyar) Dalam Transaksi Jual Beli Online di Media Sosial Menurut Perspektif Hukum Islam, Akademika: Jurnal Studi Islam, Vol. 11, No. 1 (2017), 67-68. https://www.google.co.id/search jurnal tentang hak khiyar/html, diakses 28 Juli 2018.

${ }_{25}$ Ibid, 69.

${ }^{26}$ Ibid.

${ }^{27}$ Ibid. 
1. Pembatalan akad akan dianggap sah jika pemilik hak khiyar melalui perbuatan atau pernyataan.

2. Jangka waktu khiyar jatuh tempo tanpa adanya pernyataan batal ataupun meneruskan transaksi jual beli tersebut dari pemilik khiyar, dan transaksi jual beli menjadi sempurna dan sah.

3. Obyek yang diperjual belikan hilang atau rusak ditangan pemegang hak khiyar. Apabila khiyar milik penjual, maka jual beli menjadi batal, dan apabila khiyar menjadi hak pembeli, maka jual beli itu menjadi mengikat, hukumnya berlaku, dan tidak boleh dibatalkan lagi oleh pembeli.

4. Terdapatnya penambahan nilai obyek yang diperjual belikan ditangan pembeli dan hak khiyar ada dipihaknya.

5. Menurut ulama Hanafiyah dan Hanabilah, khiyar akan berakhir apabila pemilik khiyar meninggal dunia atau wafat, karena hak khiyar bukanlah hak yang boleh diwariskan.

\section{Landasan Hukum tentang Khiyar}

\section{Al-Quran :}

Surat An-Nisa'ayat 29, yang artinya : Wahai orang-orang yang beriman, janganlah kalian memakan harta-harta kalian di antara kalian dengan cara yang batil, kecuali dengan perdagangan yang kalian saling ridha. Dan janganlah kalian membunuh diri-diri kalian, sesungguhnya Allah itu Maha Kasih Sayang kepada kalian. (Surat An-Nisa' ayat 29)

\section{Hadist}

a. Rasulullah SAW bersabda tidak dikatakan ada jual beli antara dua orang yang bertransaksi jual beli sampai mereka berpisah kecuali jual beli khiyar (jual beli yang dilakukan dengan memberikan hak pilih kepada masingmasing pihak).

b. Hadist Riwayat Al-Bukhari, yang Artinya: Dua orang yang sedang melakukan transaksi jual beli ada hak khiyar selama keduanya belum pisah. Jika mereka jujur dan terbuka, maka jual beli mereka akan diberkahi, dan jika keduanya saling mendustai dan tidak terbuka maka jual beli mereka akan ditutup keberkahannya. (HR.Al-Bukhari). 
Ijma'

Menurut Ulama Abdurahman Al-Jaziri, khiyar menurut pandangan ulama figh hukumnya diperbolehkan, karena suatu keadaan yang sangat mendesak dan dalam mempertimbangkan kemaslahatan pada masing-masing pihak yang berakad.

Hak khiyar sendiri diatur di dalam Pasal 20 poin ke 8 Kompilasi Hukum Ekonomi Syariah (KHES) yang diartikan sebagai hak pilih bagi penjual dan pembeli untuk melanjutkan atau membatalkan akad jual beli yang dilakukannya. Khiyar disyariatkan bertujuan untuk memelihara keadaan saling rela dan menjaga maslahat kedua pihak yang berakad, atau mencegah bahaya kerugian yang bisa jadi menimpa salah satu pihak yang berakad.

\section{Transaksi Jual Beli Dalam Instagram}

Instagram adalah salah satu media sosial yang pada saat ini sering digunakan untuk kegiatan jual beli online dan menjadi media sosial yang dapat membuat foto dan mengirimkannya dalam waktu yang sangat cepat, efektif dan efisien. Transaksi jual beli melalui media instagram ini menjadi alternatif yang menarik dan sangat diminati bagi pembeli pada saat ini khususnya perempuan, dan jual beli di Instagram menjadi salah satu strategi pemasaran yang dilakukan. Strategi pemasaran menyangkut tujuh konsep dalam bauran pemasaran, yaitu, product, place, price, promotion, people, process, dan physical evidence. ${ }^{28}$ Instagram merupakan salah satu media sosial yang terbilang popular untuk saat ini, yang layanannya terfokus pada media berbagi foto dan video. Tidak hanya foto dan video, kini instagram memiliki aplikasi yang memudahkan penggunanya melakukan siaran langsung (live), seperti laporan di televisi atau video singkat yang bernama Snapgram. Instagram juga memudahkan penggunanya untuk saling mengirim pesan, memberikan like, maupun berinteraksi melalui kolom komentar yang telah tersedia. Fenomena lainnya yang sangat menarik dari instagram adalah bagaimana kebanyakan orang tertarik untuk mempopulerkan akun mereka.

${ }^{28}$ Nur Anim Jauhariyah, Ahmad Munawar, Mahmudah Mahmudah. "Strategi Pemasaran Syariah dan Waiting List Terhadap Keputusan Nasabah Menggunakan Tabungan Haji pada PT BRISyariah KCP Genteng Kabupaten Banyuwangi”. Journal of Sharia Economics. 2(1). 2020, 79. 
Tujuannya adalah memperoleh jumlah follower sebanyak-banyaknya. Metode ini sebenarnya sama persis dengan twitter yang menghasilkan banyak selebtwit di Indonesia. Begitu pula dengan dunia instagram yang melahirkan sejumlah seleb dengan ribuan bahkan jutaan follower. Ketika seseorang sudah punya banyak follower, secara otomatis ia punya reputasi sehingga menarik minat dari sejumlah vendor untuk memasang iklan di akun instagram mereka. Itulah yang disebut sebagai buzzer yang mampu mendulang banyak keuntungan yang berawal dari hobi postingan di instagram atau media sosial lainnya. ${ }^{29}$

Mengenai transaksi jual beli ini secara umum (lex generalis) diatur dalam Kitab Undang-Undang Hukum Perdata (selanjutnya disebut KUHPerdata) Buku III Tentang Perikatan, khususnya Bab I sampai dengan Bab V dan beberapa pasal yang berkaitan sebagai aturan hukum umum, tetapi secara khusus (lex specialis) transaksi jual beli elektronik ini diatur dalam Undang-Undang Nomor 11 Tahun 2008 Tentang Informasi dan Transaksi Elektronik jo Undang-Undang Nomor 19 Tahun 2016 tentang Perubahan atas Undang-Undang Nomor 11 Tahun 2008 tentang Informasi dan Transaksi Elektronik (selanjutnya disebut Undang-Undang ITE). ${ }^{30}$ Menurut KUHPerdata Pasal 1457 jual beli adalah "suatu perjanjian, dengan mana pihak yang satu mengikatkan dirinya untuk menyerahkan suatu kebendaan, dan pihak yang lain untuk membayar harga yang telah dijanjikan". Hampir sama dengan perjanjian jual beli pada umumnya, perjanjian jual beli melalui instagram ini pun berawal dari penawaran dan penerimaan. Penawaran yaitu suatu perbuatan seseorang beralasan bahwa perbuatan itu sendiri sebagai ajakan untuk masuk ke dalam suatu ikatan perjanjian. Kemudian mengenai transaksi elektronik menurut Pasal 1 ayat (2) Undang-Undang ITE yaitu "perbuatan hukum yang dilakukan

29 Ariestya Ayu Pratama, "Pemanfaatan Media Sosial untuk Jual Beli Online di Kalangan Mahasiswa FISIP Universitas Airlangga Surabaya melalui Instagram”, dalam http://journal.unair.ac.id/download-fullpapers-ln16e98f953afull.pdf diakses 15 Meret 2019.

${ }^{30}$ Dhea Handariningtyas, M. Fakih, Dewi Septiana. "Transaksi Jual Beli Melalui Media Instagram Menurut Undang-Undang Nomor 11 Tahun 2008 Tentang Informasi Dan Transaksi Elektronik, Pactum Law Journal: Jurnal Bagian Hukum Perdata. Vol. 1, No. 2, (2018), 121. https://jurnal.fh.unila.ac.id/index.php/plj/article/view/1158/pdf diakses 20 Maret 2019. 
dengan menggunakan komputer, jaringan komputer, dan/atau media elektronik lainnya".

Berdasarkan pengertian di atas adanya persamaan yaitu menimbulkan hubungan hukum antar para pihak dalam bertransaksi. Undang-Undang ITE ada karena perkembangan dari KUHPerdata dan untuk mengakomodir kebutuhan masyarakat yang sekarang serba penuh dengan teknologi, karena pada transaksi jual beli ini yang dipergunakan adalah media internet, sehingga kesepakatan ataupun perjanjian yang tercipta adalah melalui internet juga. ${ }^{31}$ Hal ini telah dipertegas dalam Pasal 1 ayat (17) Undang-Undang ITE yaitu "kontrak elektronik adalah perjanjian para pihak yang dibuat melalui sistem elektronik".

Jual beli sendiri mempunyai beberapa ketentuan agar akad jual beli yang dilakukan bisa dianggap sah dan mengikat di dalam Islam. Beberapa ketentuan yang ada tersebut disebut rukun jual beli. Rukun jual beli merupakan suatu landasan dan penyangga bagi transaksi jual beli. Beberapa ulama berbeda pendapat tentang ketentuan jual beli. Madzhab Hanafi memberikan penegasan bahwa rukun jual beli hanya satu ialah ijab. Menurut Mazdhab Hanafi yang paling menjadi prinsip dalam jual beli adalah saling ikhlas dan rasa keridhaan antara para pihak untuk menyerahkan barang. Maka, apabila telah terjadi ijab jual beli tersebut telah dianggap telah terjadi. Tentu dengan adanya $i j a b$, pastinya ditemukan berbagai hal yang terkait dengannya, seperti aqidain, nilai tukar dan obyek jual beli.

Jumhur Ulama menetapkan bahwa rukun jual beli ada 4 yaitu:

1. Orang yang berakad (penjual dan pembeli)

2. Sighat ( lafal ijab dan kabul)

3. Barang yang dibeli

4. Nilai tukar pengganti barang

Khiyar Syarat merupakan suatu dispensasi bagi penjual maupun bagi pembeli untuk meneruskan atau membatalkan suatu transaksi jual beli dengan tenggat waktu tertentu. Khiyar Syarat sudah diterapkan di dalam transaksi jual beli pesanan melalui Instagram biasanya berupa open order atau jasa tiitip barang dari luar negeri sering kali terjadi apabila pembeli memesan barang hanya dengan memberikan

${ }^{31}$ Edmon Makarim, Kompilasi Hukum Telematika (Jakarta: Raja Grafindo Persada, 2004), 228. 
uang muka lalu dibatalkan oleh pembeli, atau bahkan melunasi barang lalu dibatalkan oleh pembeli dengan alasan berubah pikiran disini yang dirugikan adalah pihak penjual, lain halnya kerugian yang dialami oleh pembeli adalah barang yang telah diberikan uang muka atau bahkan dilunasi diberikan kepada pihak lain dan uang tersebut dikembalikan dengan alasan barang tidak ada, disinilah perlu diperhatikan kesepakatan awal pada saat pembelian antara penjual dan pembeli, belum lagi kondisi barang yang ternyata tidak sesuai dengan yang ada di foto meski yang dimaksud adalah sama akan mengakibatkan ketidaksesuaian dengan keinginan pemesan. Khiyar Syarat ini biasanya memiliki jangka waktu selama 1 (satu) sampai 3 (tiga) hari sesuai dengan syariat hukum Islam. Dalam hadist Rasulullah SAW menyatakan: bersumber dari Ibnu Umar, ia berkata: "Ada seorang lelaki bercerita kepada Rasulullah SAW, bahwa dia ditipu dalam jual belinya. Maka Rasulullah SAW bersabda: siapapun yang kamu ajak jual beli, katakan kepadanya: tidak boleh ada tipuan.” (HR.Muslim).

Dalam kegiatan jual beli yang dilakukan oleh masyarakat pada umumnya belum paham dengan adanya hak khiyar, penyebab utama awamnya masyarakat terhadap hak khiyar adalah kurangnya pemahaman dan pengetahuan masyarakat tentang adanya hak khiyar di dalam setiap transaksi jual beli yang dilakukan, dan terkadang ada penjual yang takut merasa rugi akibat diterapkannya hak khiyar ini, kerugian yang dialami penjual yaitu adanya pembeli yang meminta menukar barang yang telah dibelinya apabila ditemui suatu kecacatan terhadap objek jual beli tersebut, bahkan seringkali pembeli meminta (refund) pengembalian uang, inilah salah satu penyebab banyak masyarakat belum bisa menerapkan hak khiyar. Akibat yang ditimbulkan dari tidak diterapkannya hak khiyar ini di dalam masyarakat dikhawatirkan bisa menimbulkan perselisihan ataupun konflik antara kedua belah pihak apabila ada salah satu pihak yang merasa dirugikan.

Di dalam jual beli harus menerapkan nilai-nilai kejujuran dan transparan agar terhindar dari penipuan, oleh karena itu hak khiyar ini merupakan suatu jalan yang diberikan oleh agama Islam agar memberikan rasa kenyamanan dan kepuasan yang timbul dari masing-masing pihak yang bertransaksi. Di dalam Islam pada dasarnya pada setiap transaksi jual beli yang dilakukan wajib untuk diterapkannya hak khiyar, dikarenakan untuk memberi rasa keridhaan ataupun rasa keihklasan yang 
lebih dari masing-masing pihak yang melakukan proses transaksi jual beli, hak khiyar menjaga proses transaksi jual beli supaya berjalan dengan baik. Hak khiyar ini juga mengajarkan bahwa di setiap urusan yang dilakukan oleh manusia harus sesuai aturan yang sesuai dengan hukum Islam. Di dalam hukum Islam telah telah memuat bagaimana terjadinya jual beli berlangsung agar menjadi sah hukumnya di dalam agama Islam. Bahwasanya di dalam terjadinya suatu transaksi jual beli harus berlandaskan nilai-nilai kejujuran dan rasa keridhaan antara ke dua belah pihak. Allah SWT memperbolehkan adanya suatu transaksi jual beli yang sesuai dengan aturan hukum Islam, interaksi yang terjadi di dalam proses transaksi jual beli merupakan hubungan yang saling berintegrasi dengan adanya hak khiyar yang mempunyai tujuan untuk meminimalisir terjadinya sengketa ataupun perselisihan jika terjadi suatu masalah didalam proses transaksi jual beli. Islam telah mengatur tentang bagaimana agar suatu transaksi jual beli memberikan rasa keadilan dan kepuasan kepada penjual maupun kepada pembeli. Hak khiyar merupakan jalan yang terbaik yang ditetapkan hukum Islam sebagai wadah untuk memberi kesempatan berfikir ulang dan saling beritrospeksi.

Memang di dalam penerapan hak khiyar ini terkesan lebih rumit dan tidak simple dikarenakan mengandung unsur ketidakpastian terhadap suatu transaksi jual beli yang dilakukan, namun jika dilihat dari segi kepuasan para pihak hak khiyar inilah yang terbaik. Di dalam Kompilasi Hukum Ekonomi Syariah (KHES) mengenai hak khiyar yang terdapat pada Pasal 20 poin ke 8 telah mengatur hak pilih bagi penjual dan pembeli untuk melanjutkan atau membatalkan akad jual beli yang dilakukannya. Khiyar disyariatkan bertujuan untuk memelihara keadaan saling rela dan menjaga maslahat kedua pihak yang berakad, atau mencegah bahaya kerugian yang bisa jadi menimpa salah satu pihak yang berakad. Berdasarkan prinsip wajib menegakkan kejujuran dan kebenaran dalam perdagangan, maka haram bagi penjual menyembunyikan cacat barang. Apabila dalam barang yang akan dijual itu terdapat cacat yang diketahui oleh pemilik barang (penjual), maka wajiblah dia menerangkan hal itu dan tidak boleh menyembunyikannya. Menyembunyikan cacat barang dengan sengaja termasuk penipuan dan kecurangan. Khiyar hukumnya boleh berdasarkan sunnah Rasulullah SAW. 
Sejatinya di dalam melakukan kegiatan jual beli dalam Instagram harus menanamkan rasa kepedulian anatara masing-masing pihak, agar terpenuhinya kepuasan dan rasa saling ridha bagi masing-masing pihak yang bertransaksi. Di dalam pelaksanaan penerapan hak khiyar yang dilakukan oleh penjual di Instagram terdapat kiat dan usaha untuk bisa memperbaiki penerapan hak khiyar dalam jual beli melalui Instagram yaitu diantaranya:

1. Menghindari hasrat untuk mengejar keuntungan semata di dalam melakukan kegiatan jual beli.

2. Menekankan kesepakatan awal tentang kondisi barang, cara penyerahannya dan kesepakatan pembayarannya

3. Menghindari unsur penipuan di dalam kegiatan transaksi jual beli melalui pemberian informasi yang tidak jelas dalam deskripsi barang.

4. Memberikan informasi deskripsi barang sesuai dengan keadaannya dan tidak menyembunyikan informasi kondisi cacat barang

5. Menanamkan rasa saling tolong menolong di dalam melakukan kegiatan transaksi jual beli.

6. Menjaga hak dan kewajiban antara penjual dan pembeli

7. Lebih mendekatkan diri kepada Allah SWT dan lebih mendalami kembali ilmu agama.

Guna menghindari kerugian di dalam melakukan kegiatan jual beli sebaiknya pembeli lebih selektif dan lebih teliti sebelum membeli barang. Guna meminimalisir terjadinya perselisihan apabila salah satu pihak mengalami kerugian. Karena terkadang di dalam kegiatan jual beli yang dilakukan terkadang jika pembeli lupa melakukan kesepakatan mengenai kondisi barang dan pembayaran yang akan dilakukan di awal transaksi maka transaksi jual beli yang sudah dibeli tidak bisa dikembalikan lagi. Penawaran pada transaksi jual beli melalui instagram ini merupakan kegiatan penjualan yang dilakukan pihak penjual, yang mana penjual memanfaatkan instagram ini untuk menampilkan produk dagangan yang ditunjukan pada halaman timeline instagram calon pembelinya, dan diikuti dengan penerimaan oleh pihak pembeli pada awal ini harus diperjelas kesepakatan awalnya agar hak khiyar dalam jual beli tersebut dapat menjadi suatu kepastian hukum bagi para pihak, karena kadang juga terjadi penjual tidak memiliki 
barang dagangannya sendiri melainkan mengambil di pihak lain dengan istilah dropship, kejelasan akad kesepakatan harus diperjelas diawal kejujuran penjual dan pembeli dibutuhkan disini. Penjualan di instagram ini menggunakan sistem penawaran dan interaksi yang mudah dilakukan sehingga memunculkan banyak peminat yang tertarik untuk melakukan transaksi melalui media instagram ini. Banyaknya pengguna instagram menjadi salah satu alasan kuat mengapa orangorang menyukai media sosial tersebut sebagai tempat berjualan online karena lebih mudah, efisien dan efektif. Para Pihak harus dapat mendasarkan transaksi jual beli ini atas rasa kepercayaan satu sama lain karena bagaimanapun transaksi jual beli tidak lepas dari masalah perjanjian. Oleh karena perjanjian jual beli melalui Instagram yang terjadi diantara para pihak pun dilakukan secara elektronik dan tidak ada berkas perjanjian seperti pada transaksi jual beli pada umumnya maka kepercayaan menjadi awal yang melahirkan hak dan kewajiban kepada para pihak yaitu konsumen dan pelaku usaha. Hak dan kewajiban tersebut harus dilaksanakan oleh para pihak dan tidak boleh merugikan pihak lain. Hak dan kewajiban itu juga merupakan kontraprestasi dan prestasi yang harus dilaksanakan dalam hubungan hak dan kewajiban dalam jual beli melalui media Instagram.

\section{Kesimpulan}

Penerapan hak khiyar yang yang sudah berjalan dan dilakukan pada proses transaksi jual beli sudah memenuhi ketentuan hukum Islam tetapi tidak tercantum dengan jelas. Dengan diterapkannya hak khiyar ini diharapkan memberikan manfaat yang baik di dalam akad jual beli, khiyar akan membuat kegiatan jual beli berjalan sesuai dengan prinsip hukum Islam yaitu suka sama suka dan juga memberikan kemaslahatan bagi para pihak yang melakukan akad jual beli itu sendiri. Untuk para pihak yang terlibat dalam transaksi jual beli online seyogyanya agar selalu menerapkan hak khiyar di dalam setiap transaksi guna menjadi bukti bahwa para pihak mempunya itikad baik dalam transaksi jual beli dan tidak ada unsur penipuan dan terhindar dari perbuatan dosa. Allah SWT menghendaki jual beli yang dilandasi nilai-nilai kejujuran dan keadilan. Hendaknya para pihak yang terlibat dalam transaksi jual beli online selelu bersikap transparan atau saling terbuka dan tidak menyembunyikan sesuatu di dalam transaksi yang dilakukan, 
guna terciptanya keadilan dan tidak menimbulkan kerugian bagi para pihak yang melakukan transaksi.

\section{Daftar Pustaka}

Ahmad, Mustaq. Etika Bisnis dalam Islam. Jakarta: Pustaka Al-Kautsar. 2001.

Al-Fauzan, Shahih. al-Mulakhkhas al-Fiqhi Juz 2. Jakarta: Pustaka Ibnu Katsir. 2013.

Al Hadi, Abu Azam. Fikih Muamalah Kontemporer. Edisi Pertama. Cetakan Pertama. Depok: Rajawali Pers. 2017.

Ali, Zainuddin. Hukum Ekonomi Syariah. Jakarta: Sinar Grafika. 2008.

Fatwa DSN/MUI No. 05/DSN-MUI/III/2000 tentang Jual Beli Salam.

Handariningtyas, Dhea. M. Fakih, Dewi Septiana. "Transaksi Jual Beli Melalui Media Instagram Menurut Undang-Undang Nomor 11 Tahun 2008 Tentang Informasi Dan Transaksi Elektronik, Pactum Law Journal: Jurnal Bagian Hukum Perdata. Vol. 1, No. 2, (2018), 121. https://jurnal.fh.unila.ac.id/index.php/plj/article/view/1158/pdf diakses 20 Maret 2019.

Harisudin, M. Noor. Fiqh Muamalah 1. Jember: Pena Salsabila. 2014.

Ishaq. Metode Penelitian Hukum dan Penulisan Skripsi, Tesis, serta Disertasi. Cetakan Pertama. Bandung: Alfabeta. 2017.

Jaih Mubarok, Hasanudin. Fikih Mu'amalah Maliyyah Akad Jual Beli. Bandung: Simbioasa Rekatama Media. 2018.

Jauhariyah, Nur Anim., Munawar, Ahmad., Mahmudah, Mahmudah. "Strategi Pemasaran Syariah dan Waiting List Terhadap Keputusan Nasabah Menggunakan Tabungan Haji pada PT BRISyariah KCP Genteng Kabupaten Banyuwangi". Journal of Sharia Economics. 2(1). 2020, 79.

Khairi, Miftahul. Ensiklopedia Fiqh Muamalah Dalam Pandangan 4 Madzhab. Cetakan-1. Yogyakarta: Maktabah Al Khanif. 2009.

Kitab Undang-Undang Hukum Perdata.

Kompilasi Hukum Ekonomi Syariah (KHES)

Makarim, Edmon. Kompilasi Hukum Telematika. Jakarta: Raja Grafindo Persada. 2004.

Marzuki, Peter Mahmud. Penelitian Hukum. Jakarta: Kencana Prenada Media Group. 2010.

Prenada Media Group. 2014.

Prenada Media Group. 2016.

Mustofa, Imam. "Transaksi Elektronik (E-commerce) dalam perspektif Fiqih", Jurnal Hukum Islam, Vol. 10, No. 2 (Desember 2012)

Panji, Adam. Fatwa-Fatwa Ekonomi Syariah, Konsep, Metodologi,dan Implementasi pada Lembaga Keuangan Syariah. Jakarta: Sinar Grafika Offset. 2018.

Pasaribu, Charuman. Hukum Perjanjian Dalam Islam. Jakarta: Sinar Grafika. 1994. Pratama, Ariestya Ayu. "Pemanfaatan Media Sosial untuk Jual Beli Online di Kalangan Mahasiswa FISIP Universitas Airlangga Surabaya melalui 
Instagram", dalam $\quad$ http://journal.unair.ac.id/download-fullpapers$\underline{\ln 16 \mathrm{e} 98 \mathrm{f} 953 \mathrm{afull} . p d f}$ diakses 15 Meret 2019.

Qs Al-Baqarah ayat 282.

Qs Surat An-Nisa'ayat 29.

Sifa', Moh. Agus. "Mekanisme Pasar dalam Perspektif Islam". Journal of Sharia Economics. 2(1). 2020, 30.

Soejonno, Abdurahman. Metode Penelitian Suatu Pemikiran dan Penerapan. Cetakan ke-2. Jakarta: Rineke Cipta. 2005.

Subhan, Moh. Ah. Hak Pilih (Khiyar) Dalam Transaksi Jual Beli Online di Media Sosial Menurut Perspektif Hukum Islam, Akademika: Jurnal Studi Islam, Vol. 11, No. 1 (2017), 67-68. https://www.google.co.id/search jurnal tentang hak khiyar/html, diakses 28 Juli 2018.

Sudarsono, Heri. Konsep Ekonomi Islam Suatu Pengantar. Yogyakarta: Ekonisia. 2003.

Sunarso, Siswanto. Hukum Informasi Dan Transaksi Elektronik. Jakarta. Rineka Cipta. 2009.

Umar, Chapra. Masa Depan Ekonomi, Sebuah Tinjauan Islam. Jakarta: Gema Insani Press. 2001.

Yazid, M. Fiqh Muamalah dan Implementasinya dalam Lembaga Keuangan Syari'ah. Cetakan Pertama. Yogyakarta: Logung Pustaka. 2009.

Zuhayli, Wahbah. Al-Fiqhu asy-syafi'iyyah Al-Muyassar. Beirut: darul Fikr. 2008. 